2002s-54

\title{
Incentives? The Effect of Profit Sharing Plans Offered by Previous Employers on Current Wages.
}

\author{
Daniel Parent
}

Série Scientifique

Scientific Series

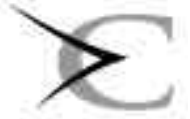

CI RANO

Montréal

Mai 2002 


\section{CIRANO}

Le CIRANO est un organisme sans but lucratif constitué en vertu de la Loi des compagnies du Québec. Le financement de son infrastructure et de ses activités de recherche provient des cotisations de ses organisationsmembres, d'une subvention d'infrastructure du ministère de la Recherche, de la Science et de la Technologie, de même que des subventions et mandats obtenus par ses équipes de recherche.

CIRANO is a private non-profit organization incorporated under the Québec Companies Act. Its infrastructure and research activities are funded through fees paid by member organizations, an infrastructure grant from the Ministère de la Recherche, de la Science et de la Technologie, and grants and research mandates obtained by its research teams.

\section{Les organisations-partenaires / The Partner Organizations}

-École des Hautes Études Commerciales

-École Polytechnique de Montréal

-Université Concordia

-Université de Montréal

-Université du Québec à Montréal

-Université Laval

-Université McGill

-Ministère des Finances du Québec

-MRST

-Alcan inc.

- AXA Canada

-Banque du Canada

-Banque Laurentienne du Canada

- Banque Nationale du Canada

- Banque Royale du Canada

- Bell Canada

- Bombardier

- Bourse de Montréal

-Développement des ressources humaines Canada (DRHC)

-Fédération des caisses Desjardins du Québec

-Hydro-Québec

-Industrie Canada

-Pratt \& Whitney Canada Inc.

-Raymond Chabot Grant Thornton

-Ville de Montréal

(C) 2002 Daniel Parent. Tous droits réservés. All rights reserved. Reproduction partielle permise avec citation du document source, incluant la notice (C).

Short sections may be quoted without explicit permission, if full credit, including (C) notice, is given to the source.

Les cahiers de la série scientifique (CS) visent à rendre accessibles des résultats de recherche effectuée au CIRANO afin de susciter échanges et commentaires. Ces cahiers sont écrits dans le style des publications scientifiques. Les idées et les opinions émises sont sous l'unique responsabilité des auteurs et ne représentent pas nécessairement les positions du CIRANO ou de ses partenaires.

This paper presents research carried out at CIRANO and aims at encouraging discussion and comment.

The observations and viewpoints expressed are the sole responsibility of the authors. They do not necessarily represent positions of CIRANO or its partners.

\section{ISSN 1198-8177}




\title{
Incentives? The Effect of Profit Sharing Plans Offered by Previous Employers on Current Wages".
}

\author{
Daniel Parent ${ }^{\dagger}$
}

Dans cette étude, j'examine le lien entre la rémunération versée aux travailleurs et l'utilisation de programmes de partage de profits («profit sharing») par l'employeur actuel ainsi que les employeurs précédents. Avec des données du National Longitudinal Survey of Youth, je trouve que l'effet des programmes de partage de profits dont ont bénéficié les travailleurs dans leurs emplois antérieurs à leur emploi actuel est économiquement et statistiquement significatif. De fait, tenir compte de ces programmes dans une équation de gains standard réduit de façon très substantielle ou même totalement l'effet de programmes similaires offerts par l'employeur actuel. Ce dernier résultat laisse planer un doute sérieux sur une explication standard (quoique problématique) donnée pour justifier l'existence de l'effet positif des programmes de partage de profits, à savoir un effet incitatif à l'effort. Les résultats sont davantage cohérents avec le fait que les travailleurs bénéficiant de tels programmes acquièrent des habiletés transférables d'un employeur à un autre.

In this paper, I investigate the relationship between wages and the use of profit sharing plans by both current and past employers. Using data from the National Longitudinal Survey of Youth, I find that when I control for the number of years on profit sharing plans prior to the current job, the wage effect of those previous plans is both economically and statistically significant while the wage effect of current plans is markedly reduced, if not completely eliminated. This result sheds doubt on a simple incentive-for-effort explanation for the wage/productivity impact previously measured and suggests that an alternative mechanism based on skill acquisition is likely to play a role.

Mots-clés: Rémunération incitative, qualifications, partage de profits.

Keywords: Incentive pay, skills, profit sharing.

\footnotetext{
* The author wishes to thank Bentley MacLeod for many discussions on this topic. Financial support from the Social Sciences and Humanities Research Council of Canada is gratefully acknowledged.

$\dagger$ CIRANO and Department of Economics, McGill University, 855 Sherbrooke St. W., Montréal, Québec, H3A 2T7, CANADA
} 


\section{Introduction}

The evidence on the productivity impact of profit sharing plans suggests that such plans are associated with increases in both productivity and wages, even when controlling for unobserved worker characteristics (Kruse (1993), Kruse (1992), Azfar and Danninger (2001)). At the risk of oversimplifying, the traditional way of looking at profit sharing plans has been to view them as incentive mechanisms when individual output is either difficult to measure relative to team output or when the firm wants to foster greater cooperation between workers. As is well known from tournament models, using contracts based on individual measures of performance can be counter productive in environments where each worker can affect other workers' output (Lazear (1989)). In such circumstances, pay compression or teams rewards may be preferable.

As has been appreciated for a long time, however, profit-sharing plans as an incentive device suffer from the free-rider problem: why would an individual in a group of $\mathrm{N}$ workers really be induced to provide effort when he will get only $1 / \mathrm{N}$ of the increased productivity or profits. Put differently, why would he not rely on the N-1 other workers' efforts to increase his wage without changing his own behavior. At the same time, explanations based on the possible beneficial effects of profit sharing plans on team morale, worker cooperation, better internalization of the firm's objectives by the workers, etc., suffer from the problem that they are very difficult to verify empirically. An example of these latter channels is offered in FitzRoy and Kraft (1987). They first argue that profit sharing plans are more likely to occur in environments in which cooperation is easier to sustain or is the norm and where "horizontal" monitoring by co-workers provides a good (and relatively cheap) substitute to direct monitoring by managers. Then, although the direct incentive effect is small due to the $1 / \mathrm{N}$ problem, the positive externalities created by cooperation are sufficiently strong to induce workers to in fact collaborate, provided that the firms has "social sanctions" at its disposal.

An alternative, but closely related explanation, indirectly touched upon by FitzRoy and Kraft (1987) and more directly by Azfar and Danninger (2001) is that firms may use profit sharing schemes because they provide a simple way for the firm to commit itself to reward firm-specific skills acquired through on-the-job formal or informal training programs. Why the need for commitment? Simply because by their very nature, firm specific skills, in addition to being very difficult to contract upon, have no market value, and thus firms cannot be trusted to share the rents over those skills with their workers unless one invokes reputation effects. By writing an explicit contract in which it is specified that workers get a certain percentage of the profits, workers can feel more confident that they will not be held up ex post. Consequently, they may choose to devote some time to learning firm-specific skills. ${ }^{1}$ In fact, this is essentially what Azfar and Danninger (2001) find with data from the NLSY: the hazard out of employment is lower for workers on profit sharing, wage growth is stronger, and workers on profit sharing are more likely to be trained by the firm. While the effect on the hazard combined with the greater incidence of training do provide some evidence of workers acquiring firm-specific skills, the wage growth results are basically uninformative on that issue. ${ }^{2}$ On the one hand, if it is true that skill acquisition tends to go hand in hand with profit sharing, it may be that some of those skills that the workers are acquiring are actually portable across employers. This would drive the market value of the workers up. On the other hand, the wage effect may also result from purely incentive effects related to effort.

The objective in this paper is to pursue the line of argument outlined in the

\footnotetext{
${ }^{1}$ Note that the $1 / \mathrm{N}$ problem is still an issue here, though.

${ }^{2}$ Even the results for the hazard out of employment are not immune to the possibility that unobserved worker characteristics may be driving the effect.
} 
previous paragraph. If it is true that profit sharing plans are associated with greater acquisitions of skills, then it would be interesting to know whether any of those skills are transferable across employers. Evidence that workers on profit sharing plans with previous employers earn more than other similar workers would be hard to reconcile with an incentive-for-effort based explanation. In other words, principal-agent problems specific to an employment relationship do not carry over to subsequent relationships. Thus, profit sharing plans may serve instead as a mechanism under which workers are more inclined to devote time to skill acquisition activities. ${ }^{3}$

To analyse these potential effects, I use the same empirical framework as the one used to study the effect of experience or firm tenure on wages (e.g. Abraham and Farber (1987), Altonji and Shakotko (1987), Topel (1991)). That is, allowing for the possibility that skill acquisition may matter for workers on profit sharing plans, instead of using the traditional dummy variable for the presence of profit sharing, I make use of polynomials in the number of years one has been on profit sharing with the current employer as well as the number of years on profit sharing with all previous employers. To control for the endogeneity of these regressors, I use the instrumental variable methodology proposed in Altonji and Shakotko (1987).

I find strong evidence that profit sharing plans' effects are transferable across employers. In fact, once I control for years on profit sharing with previous employers, the wage effect of years on profit sharing with the current employer vanishes. This result is hard to reconcile with the notion that profit sharing plans increase productivity through a "pure" incentive-for-effort mechanism. It seems more consistent with the idea that skill acquisition may result as a consequence of participating in a profit sharing plan.

\section{The Data}

The data set used in this paper is the National Longitudinal Survey of Youth, or NLSY. Individuals in the NLSY were between the ages of fourteen and twenty-one on January 1, 1979. I use up to eight yearly observations worker (from 1988 to 1996). ${ }^{4}$ One advantage of the NLSY is that it allows one to follow workers from the time they make their first long-term transition to the labor force. I use the same sample selection criteria as those used by Gibbons, Katz, Lemieux, and Parent (2002) and readers are referred to that paper for more details on the criteria used to construct this NLSY sample. I am left with a sample of 27,278 observations on 5,451 workers that satisfy these sample-selection criteria. Summary statistics are reported in Table 1 for males and females separately.

Starting in 1988, workers were asked whether profit sharing was made available to them by their current/most recent employer. Thus, there may be cases of workers not enrolling into the profit sharing plan offered by their employer. Consequently, because there is no way to identify those individuals, they will be falsely classified as being on profit sharing plan. The result will be to introduce an attenuation bias in the estimated coefficients. ${ }^{5}$

\footnotetext{
${ }^{3}$ Naturally, the distinction between what I call the "incentive-for-effort" explanation and the skill acquisition story may be fairly blurred in reality: acquiring more skills may be seen by the firm as indeed working harder or, at least, working better.

${ }^{4}$ There was no interview in 1995.

${ }^{5}$ The analysis contained in Card (1996) (pp. 958-960) in his work on the effect of union status on wages is totally applicable here. More particularly, he shows that the presence of covariates in a regression of wages on observed union status exacerbates the attenuation toward zero. The only difference in this case is that the probability of a "false positive" may be larger here depending upon the extent to which some workers do not enroll in profit sharing plans offered by their employer.
} 


\section{The Wage Effects of Profit Sharing Plans.}

\subsection{Estimation Framework}

Given that the NLSY data does not contain firm-level data, such as productivity per worker, I will use instead wage data in addition to the question asked to workers about the availability of profit sharing plans. ${ }^{6}$ I then exploit the longitudinal dimension of the NLSY, including the fact that we know whether a worker stays in the same job or changes employer, to estimate fixed-effect and instrumental variable models of the wage impact of such plans.

In levels, the models I estimate are variants of:

$$
w_{i j t}=X_{i j t} \Gamma+Z_{i j t} \Gamma_{2}+Y P S C E_{i j t} \delta_{1}+Y P S P E_{i t} \delta_{2}+\alpha_{i}+\theta_{i j}+\varepsilon_{i j t}
$$

where $w_{i j t}$ is the $\log$ hourly wage of individual $\mathrm{i}$ in job $\mathrm{j}$ at time $\mathrm{t}, X_{i t}$ is a vector of individual characteristics which may be time-varying, $Z_{i j t}$ is the vector of timevarying job-match attributes (e.g. tenure with the current employer), YPSCE $E_{i j t}$ is the number of years on profit sharing with the current employer, and YPSPE represents the number of years on profit sharing with all previous employers (higher order terms for $Y P S C E$ and $Y P S P E$ are suppressed to save space but they will be estimated as well). In addition to these measured characteristics, I assume that the log-wage depends on a person-specific component $\left(\alpha_{i}\right)$, a time-invariant job-match component $\left(\theta_{i j)}\right)$, and a residual i.i.d term $\left(\varepsilon_{i j t}\right)$.

As is well known, estimating equation (1) in levels may produce a biased estimate of $\delta_{1}$ if profit sharing plans tend to be offered to intrinsically more productive individuals (high $\alpha$ 's) or to workers in particularly good matches (high $\theta$ 's). To alleviate this problem I borrow from the literature on the "employer tenure effect" by adapting Altonji and Shakotko (1987)'s IV strategy to the present context. The number of years on profit sharing plans with the current employer is instrumented with its deviation from job-match means while the number of years on profit sharing with previous employers is instrumented with its deviations from individual means. By construction, the first instrument is orthogonal to the unobserved job-match component while the second instrument is orthogonal to the unobserved personspecific component. ${ }^{7}$

\subsection{Results}

Results are presented in tables 2 and 3. As we can see in both tables, allowing for the effect of profit sharing to be non-linear in the ordinary least-squares case seems to represent a better empirical description compared to using a simple linear term (or just a dummy). Note that I also experimented with using a complete set of dummies for each number of accumulated year on profit sharing instead of a polynomial. Although not shown here (but available upon request), the visual pattern clearly shows non-linearities. Another important thing to note also is that since I am estimating cubic functions in actual years of labor market experience and employer tenure, the non linear effect of profit sharing reported here is not the result of the polynomial in years on profit sharing picking up secular wage growth.

Once I include the number of years on profit sharing with previous employers (cols. 4-5, 7-8), the effect of currently being on profit sharing decreases substantially, even with OLS. This is easily seen once we note that the net effect of years on profit sharing with the current employer is simply the difference between the coefficient

\footnotetext{
${ }^{6}$ It is not possible to know the exact nature of the plan (cash based or deferred based plan, such as a pension fund in which firms put a percentage of their profits).

${ }^{7}$ Higher-order terms are also instrumented in the same way.
} 
for current years minus the coefficient for years with previous employers. ${ }^{8}$ Indeed, the IV results suggest that any contemporaneous effect of profit sharing is due in part to selectivity biases which arise out of the fact that better matches are more likely to be on profit sharing (columns 5 and 6 in Tables 2 and 3), and in part to the fact that some of the skills acquired while being on profit sharing have market value (columns 7 and 8 in Tables 2 and 3).

\section{Conclusion}

The results contained in this paper are suggestive that one likely channel for the productivity effect of profit sharing plans is linked to skill acquisition, which is consistent with the previous analysis contained in Azfar and Danninger (2001). Perhaps more importantly, the fact that profit sharing plans offered by previous employers have a strong positive impact on the current wage appears difficult to reconcile with the view that the role of such plans is solely to "solve" a principalagent problem.

\section{References}

Abraham, K. G. and H. S. Farber (1987, June). Job duration, seniority, and earnings. American Economic Review 77(3), 278-297.

Altonji, J. G. and R. A. Shakotko (1987, July). Do wages rise with job seniority? Review of Economic Studies, 54(3), 437-459.

Azfar, O. and S. Danninger (2001, April). Profit sharing, employment stability, and wage growth. Industrial and Labor Relations Review 54(3), 619-630.

Card, D. (1996, July). The effect of unions on the structure of wages: A longitudinal analysis. Econometrica 64(4), 957-979.

FitzRoy, F. and K. Kraft (1987, February). Cooperation, productivity, and profit sharing. Quarterly Journal of Economics 85(1), 23-35.

Gibbons, R., L. Katz, T. Lemieux, and D. Parent (2002). Comparative advantage, learning, and sectoral wage determinition. National Bureau of Economic Research Working Paper 8889, Cambridge, MA.

Kruse, D. (1992, January). Profit sharing and productivity: Microeconomic evidence from the united states. Economic Journal 102, 24-36.

Kruse, D. L. (1993). Profit Sharing: Does it Make a Difference? Kalamazoo, Michigan: W.E. Upjohn Institute.

Lazear, E. P. (1989, December). Pay equality and industrial politics. Journal of Political Economy 97, 561-580.

Topel, R. (1991, February). Specific capital, mobility, and wages: Wages rise with job seniority. Journal of Political Economy 99(1), 145-176.

\footnotetext{
${ }^{8}$ Defining total years on profit sharing as TOTYPS $=Y P S C E+Y P S P E$, equation (1) can then be re-written as (ignoring other covariates):

$w_{i j t}=(Y P S C E) \delta_{1}+(T O T Y P S-Y P S C E) \delta_{2}+\varepsilon=(Y P S C E)\left(\delta_{1}-\delta_{2}\right)+(Y P S P S) \delta_{2}+\varepsilon$
} 


\begin{tabular}{|c|c|c|}
\hline \multicolumn{3}{|c|}{ Table 1. Summary Statistics: NLSY 1988-1996 } \\
\hline & Females & Males \\
\hline Fraction Offered Profit Sharing & $32.9 \%$ & $33.6 \%$ \\
\hline Age & 29.9 & 29.8 \\
\hline Years of Completed Education & 13.8 & 13.7 \\
\hline Fraction Nonwhite & $21.8 \%$ & $20.2 \%$ \\
\hline Years ofActual Labor Market Experience & 7.9 & 8.5 \\
\hline Employer Tenure & 4.1 & 4.0 \\
\hline Fraction Married & $54.5 \%$ & $56 \%$ \\
\hline Fraction Covered by Union Contract & $14.7 \%$ & $16.9 \%$ \\
\hline Real (\$79) Hourly Wage & 5.72 & 6.85 \\
\hline Number of Workers & 2,621 & 2,830 \\
\hline Number of Observations & 12,718 & 14,560 \\
\hline
\end{tabular}




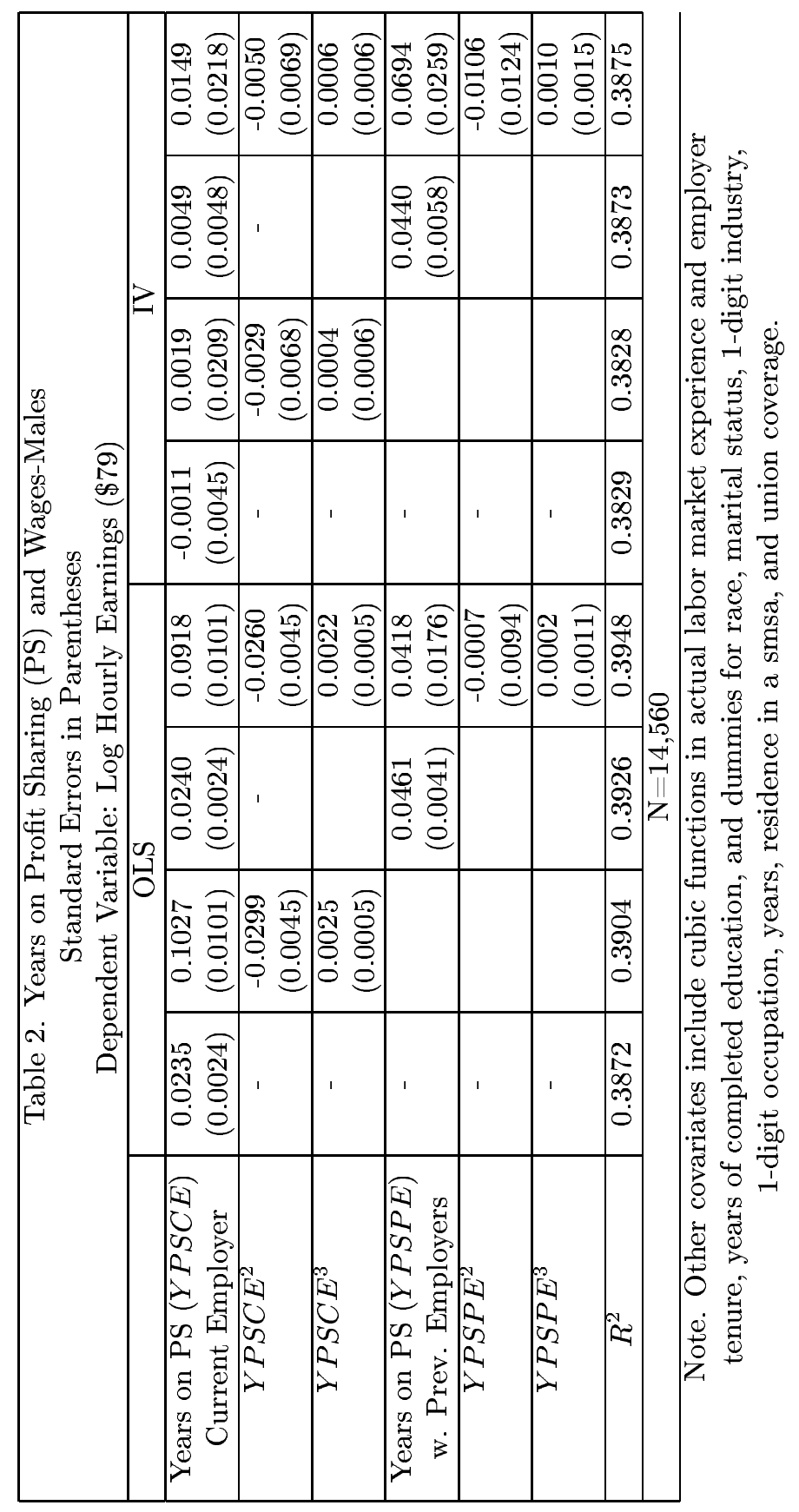




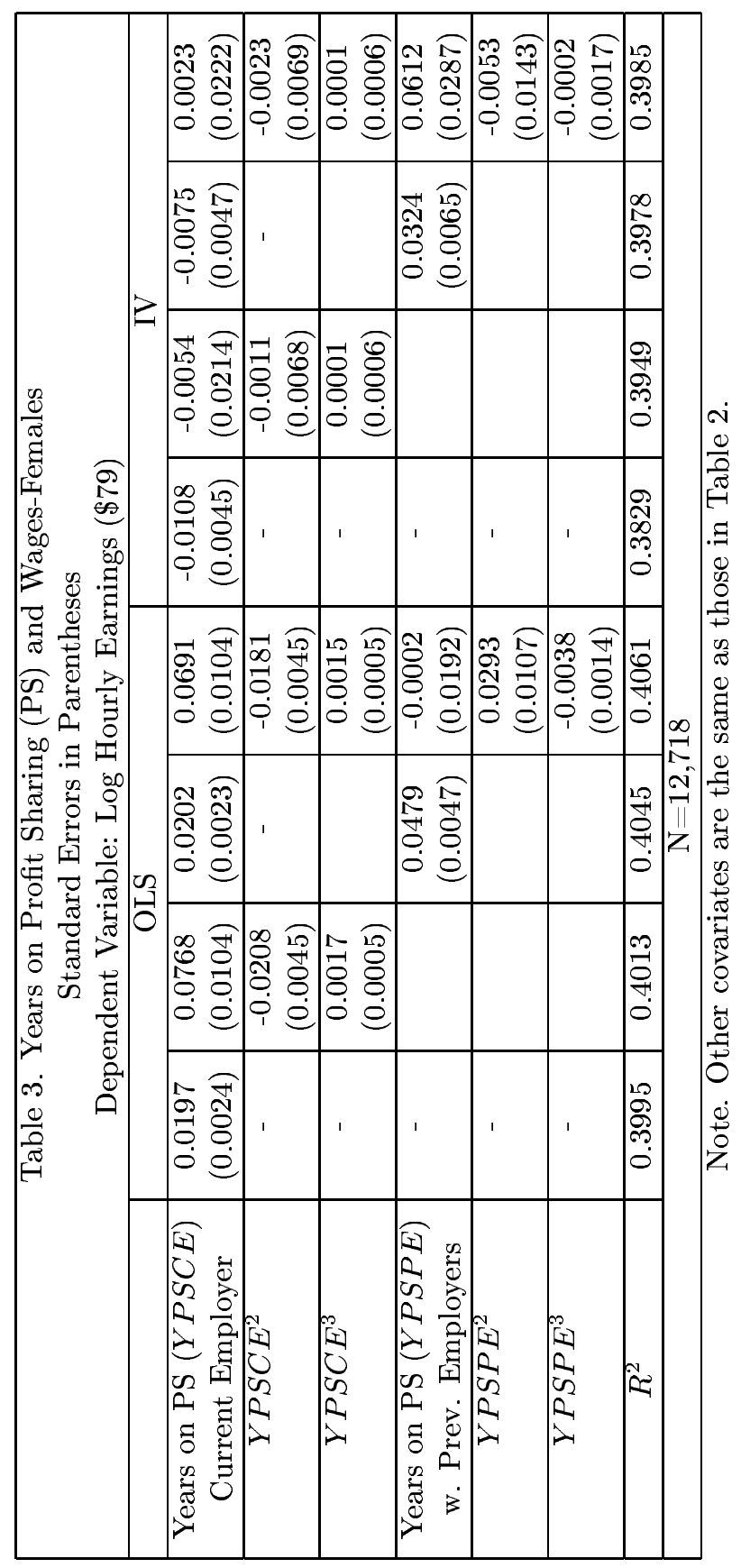




\section{Liste des publications au CIRANO*}

Série Scientifique / Scientific Series (ISSN 1198-8177)

2002s-54 Incentives? The Effect of Profit Sharing Plans Offered by Previous Employers on Current Wages / Daniel Parent

2002s-53 Multi-Task Learning For Option Pricing / J. Ghosn et Y. Bengio

2002s-52 Input Decay: Simple and Effective Soft Variable Selection / N. Chapados et Y. Bengio

2002s-51 On Out-of-Sample Statistics for Time-Series / F. Gingras, Y. Bengio et C. Nadeau

2002s-50 Forecasting Non-Stationary Volatility with Hyper-Parameters / Y. Bengio et C. Dugas

2002s-49 Cost Functions and Model Combination for VaR-based Asset Allocation using Neural Networks / N. Chapados et Y. Bengio

2002s-48 Experiments on the Application of IOHMMs to Model Financial Returns Series / Y. Bengio, V.-P. Lauzon et R. Ducharme

2002s-47 Valorisation d'Options par Optimisation du Sharpe Ratio / Y. Bengio, R. Ducharme, O. Bardou et N. Chapados

2002s-46 Incorporating Second-Order Functional Knowledge for Better Option Pricing / C. Dugas, Y. Bengio, F. Bélisle, C. Nadeau et R. Garcia

2002s-45 Étude du Biais dans le Prix des Options / C. Dugas et Y. Bengio

2002s-44 Régularisation du Prix des Options : Stacking / O. Bardou et Y. Bengio

2002s-43 Monotonicity and Bounds for Cost Shares under the Path Serial Rule / Michel Truchon et Cyril Téjédo

2002s-42 Maximal Decompositions of Cost Games into Specific and Joint Costs / Michel Moreaux et Michel Truchon

2002s-41 Maximum Likelihood and the Bootstrap for Nonlinear Dynamic Models / Sílvia Gonçalves, Halbert White

2002s-40 Selective Penalization Of Polluters: An Inf-Convolution Approach / Ngo Van Long et Antoine Soubeyran

2002s-39 On the Mediational Role of Feelings of Self-Determination in the Workplace: Further Evidence and Generalization / Marc R. Blais et Nathalie M. Brière

2002s-38 The Interaction Between Global Task Motivation and the Motivational Function of Events on Self-Regulation: Is Sauce for the Goose, Sauce for the Gander? / Marc R. Blais et Ursula Hess

2002s-37 Static Versus Dynamic Structural Models of Depression: The Case of the CES-D / Andrea S. Riddle, Marc R. Blais et Ursula Hess

* Consultez la liste complète des publications du CIRANO et les publications elles-mêmes sur notre site Internet : 
2002s-36 A Multi-Group Investigation of the CES-D's Measurement Structure Across Adolescents, Young Adults and Middle-Aged Adults / Andrea S. Riddle, Marc R. Blais et Ursula Hess

2002s-35 Comparative Advantage, Learning, and Sectoral Wage Determination / Robert Gibbons, Lawrence F. Katz, Thomas Lemieux et Daniel Parent

2002s-34 European Economic Integration and the Labour Compact, 1850-1913 / Michael Huberman et Wayne Lewchuk

2002s-33 Which Volatility Model for Option Valuation? / Peter Christoffersen et Kris Jacobs

2002s-32 Production Technology, Information Technology, and Vertical Integration under Asymmetric Information / Gamal Atallah

2002s-31 Dynamique Motivationnelle de l'Épuisement et du Bien-être chez des Enseignants Africains / Manon Levesque, Marc R. Blais, Ursula Hess

2002s-30 Motivation, Comportements Organisationnels Discrétionnaires et Bien-être en Milieu Africain : Quand le Devoir Oblige / Manon Levesque, Marc R. Blais et Ursula Hess

2002s-29 Tax Incentives and Fertility in Canada: Permanent vs. Transitory Effects / Daniel Parent et Ling Wang

2002s-28 The Causal Effect of High School Employment on Educational Attainment in Canada / Daniel Parent

2002s-27 Employer-Supported Training in Canada and Its Impact on Mobility and Wages / Daniel Parent

2002s-26 Restructuring and Economic Performance: The Experience of the Tunisian Economy / Sofiane Ghali and Pierre Mohnen

2002s-25 What Type of Enterprise Forges Close Links With Universities and Government Labs? Evidence From CIS 2 / Pierre Mohnen et Cathy Hoareau

2002s-24 Environmental Performance of Canadian Pulp and Paper Plants : Why Some Do Well and Others Do Not ? / Julie Doonan, Paul Lanoie et Benoit Laplante

2002s-23 A Rule-driven Approach for Defining the Behavior of Negotiating Software Agents / Morad Benyoucef, Hakim Alj, Kim Levy et Rudolf K. Keller

2002s-22 Occupational Gender Segregation and Women's Wages in Canada: An Historical Perspective / Nicole M. Fortin et Michael Huberman

2002s-21 Information Content of Volatility Forecasts at Medium-term Horizons / John W. Galbraith et Turgut Kisinbay

2002s-20 Earnings Dispersion, Risk Aversion and Education / Christian Belzil et Jörgen Hansen

2002s-19 Unobserved Ability and the Return to Schooling / Christian Belzil et Jörgen Hansen

2002s-18 Auditing Policies and Information Systems in Principal-Agent Analysis / MarieCécile Fagart et Bernard Sinclair-Desgagné

2002s-17 The Choice of Instruments for Environmental Policy: Liability or Regulation? / Marcel Boyer, Donatella Porrini

2002s-16 Asymmetric Information and Product Differentiation / Marcel Boyer, Philippe Mahenc et Michel Moreaux

2002s-15 Entry Preventing Locations Under Incomplete Information / Marcel Boyer, Philippe Mahenc et Michel Moreaux 
2002s-14 On the Relationship Between Financial Status and Investment in Technological Flexibility / Marcel Boyer, Armel Jacques et Michel Moreaux

2002s-13 Modeling the Choice Between Regulation and Liability in Terms of Social Welfare / Marcel Boyer et Donatella Porrini

2002s-12 Observation, Flexibilité et Structures Technologiques des Industries / Marcel Boyer, Armel Jacques et Michel Moreaux

2002s-11 Idiosyncratic Consumption Risk and the Cross-Section of Asset Returns / Kris Jacobs et Kevin Q. Wang

2002s-10 The Demand for the Arts / Louis Lévy-Garboua et Claude Montmarquette

2002s-09 Relative Wealth, Status Seeking, and Catching Up / Ngo Van Long, Koji Shimomura

2002s-08 The Rate of Risk Aversion May Be Lower Than You Think / Kris Jacobs

2002s-07 A Structural Analysis of the Correlated Random Coefficient Wage Regression Model / Christian Belzil et Jörgen Hansen

2002s-06 Information Asymmetry, Insurance, and the Decision to Hospitalize / Åke Blomqvist et Pierre Thomas Léger

2002s-05 Coping with Stressful Decisions: Individual Differences, Appraisals and Choice / Ann-Renée Blais

2002s-04 A New Proof Of The Maximum Principle / Ngo Van Long et Koji Shimomura

2002s-03 Macro Surprises And Short-Term Behaviour In Bond Futures / Eugene Durenard et David Veredas

2002s-02 Financial Asset Returns, Market Timing, and Volatility Dynamics / Peter F. Christoffersen et Francis X. Diebold

2002s-01 An Empirical Analysis of Water Supply Contracts / Serge Garcia et Alban Thomas

2001s-71 A Theoretical Comparison Between Integrated and Realized Volatilities Modeling / Nour Meddahi

2001s-70 An Eigenfunction Approach for Volatility Modeling / Nour Meddahi

2001s-69 Dynamic Prevention in Short Term Insurance Contracts / M. Martin Boyer et Karine Gobert

2001s-68 Serial Cost Sharing in Multidimensional Contexts / Cyril Téjédo et Michel Truchon

2001s-67 Learning from Strike / Fabienne Tournadre et Marie-Claire Villeval

2001s-66 Incentives in Common Agency / Bernard Sinclair-Desgagné

2001s-65 Detecting Mutiple Breaks in Financial Market Volatility Dynamics / Elena Andreou et Eric Ghysels

2001s-64 Real Options, Preemption, and the Dynamics of Industry Investments / Marcel Boyer, Pierre Lasserre, Thomas Mariotti et Michel Moreaux

2001s-63 Dropout, School Performance and Working while in School: An Econometric Model with Heterogeneous Groups / Marcel Dagenais, Claude Montmarquette et Nathalie Viennot-Briot

2001s-62 Derivatives Do Affect Mutual Funds Returns : How and When? / Charles Cao, Eric Ghysels et Frank Hatheway 